\title{
S-100B protein and chronic subdural hematoma
}

\section{Miguel Gelabert-González*, Eduardo Aran-Echabe and Ramón Serramito-García}

Department of Surgery, University of Santiago de Compostela, Santiago de Compostela, Spain

*Correspondence: miguel.gelabert@usc.es

Edited by:

Bryan G. Young, London Health Science Center, Canada

Reviewed by:

Bryan G. Young, London Health Science Center, Canada

Andrew S. Little, Barrow Neurological Institute, USA

Allen Waziri, University of Colorado School of Medicine, USA

\section{A commentary on}

Case report: extreme levels of serum $S$-100B in a patient with chronic subdural hematoma

by Persson M. E., Thelin E. P., and Bellander B. M. (2012) Front. Neurol.3:170. doi: 10.3389/ fneur.2012.00170

We are surprised by the conclusions of a recent paper by Persson et al. (2012), "Case report: extreme levels of serum S-100B in a patient with chronic subdural hematoma," which suggest that S-100B protein is an important marker for chronic subdural hematoma (CSDH). In our opinion, and that of other authors, S-100B is a significant marker of multiple neurological pathologies.

Chronic subdural hematoma is a relatively common complication, especially among the elderly, where the incidence is estimated as $7.4 / 100,000$. Two circumstances account for its high incidence among the elderly; the extensive brain atrophy often found in the elderly or alcoholics, and long-term use anticoagulant (Gelabert et al., 2001). CSDH in patients less than
50 years old is rare, and when it does occur it usually points to a predisposing factor, as in this case, where a brain metastasis led to the formation of a hematoma (GelabertGonzález et al., 2012).

Moreover, while the radiological image of the patient in their study shows a hematoma, it is of small and therefore leads one to question how this can be responsible for such a midline shift. This suggests that something more must be involved, as was revealed at autopsy where a metastases was identified.

In a recent paper, Kruijff and Hoekstra (2012) state that the protein S-100B is probably the best biomarker for melanoma, having potential to identify high-risk stage III melanoma patients who may benefit from adjuvant systematic treatment. Since an effective (adjuvant) therapy for locoregional metastatic and disseminated melanoma has only been recently introduced, the diagnostic of S-100B, they argue, is set to increase in the near future.

It therefore appears inappropriate to consider differential levels of S-100B as indicative of the evolution of $\mathrm{CSH}$, as suggested by the paper's title, since they can be more indicative of a melanoma and its metastasis.

\section{REFERENCES}

Gelabert, M., López, E., and Fernández, J. M. (2001). Chronic subdural hematoma treated by burr holes and closed drainage system: a review of 630 cases. Med. Principles Pract. 10, 41-47.

Gelabert-González, M., Frieiro-Dantas, C., SerramitoGarcía, R., Díaz-Cabanas, L., Aran-Echabe, E., Rico-Cotelo, M., et al. (2012). Chronic subdural hematoma in young patients. Neurocirugia (Astur.) pii: S1130-S1473(12)00156-X. doi: 10.1016/j. neucir.2012.08.002

Kruijff, S., and Hoekstra, H. J. (2012). The current status of S-100B as a biomarker in melanoma. Eur. J. Surg. Oncol. 38, 281-285.

Persson, M. E., Thelin, E. P., and Bellander, B. M. (2012). Case report: extreme levels of serum S-100B in a patient with chronic subdural hematoma. Front. Neurol.3:170. doi: 10.3389/fneur.2012.00170

Received: 31 January 2013; accepted: 28 February 2013; published online: 15 March 2013.

Citation: Gelabert-González M, Aran-Echabe E and Serramito-García R (2013) S-100B protein and chronic subdural hematoma. Front. Neurol. 4:24. doi: 10.3389/ fneur.2013.00024

This article was submitted to Frontiers in Neurocritical and Neurohospitalist Care, a specialty of Frontiers in Neurology Copyright $\odot 2013$ Gelabert-González, Aran-Echabe and Serramito-García. This is an open-access article distributed under the terms of the Creative Commons Attribution License, which permits use, distribution and reproduction in other forums, provided the original authors and source are credited and subject to any copyright notices concerning any third-party graphics etc. 